\title{
Different techniques for aortic valve repair and the associated root reconstruction - prospective long-term follow-up of the first 100 patients
}

\author{
Marek J. Jasinski ${ }^{1}$, Radosław Gocol ${ }^{1}$, Marcin Malinowski ${ }^{1}$, Damian Hudziak ${ }^{1}$, Piotr Duraj ${ }^{1}$, \\ Joanna Frackiewicz ${ }^{2}$, Tomasz Kargul ${ }^{1}$, Marek A. Deja ${ }^{1}$, Stanisław Woś ${ }^{1}$
}

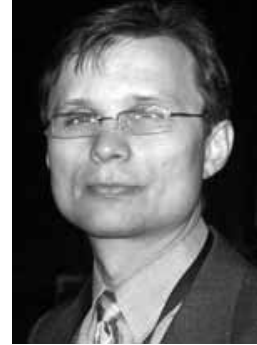

${ }^{1}$ School of Medicine, Medical University of Silesia, Chair and Department of Cardiac Surgery, Katowice, Poland

${ }^{2}$ Department of Rehabilitation, Medical University of Silesia, Katowice, Poland

Kardiochirurgia i Torakochirurgia Polska 2014; 11 (4): 373-380

\begin{abstract}
Introduction: The advantages of aortic valve and aortic root reconstructive surgery include the provision of natural postoperative valve hemodynamics and the avoidance of prosthetic valve-related complications. A systematic approach based on functional classification of aortic regurgitation allows standardization and reproducibility. Its potential applicability, however, is limited by the relative lack of long-term follow-up data. Aim: To achieve the long term results of aortic valve and root repair in prospectively recruited group of 100 patients operated on during first seven years.

Material and methods: Between the years 2003 and 2013, 225 consecutive patients (175 male, 50 female, mean age 51.3 years) with severe aortic regurgitation and aortic root enlargement underwent aortic valve repair or sparing surgery. The first 100 patients operated between 2003 and 2009 were prospectively enrolled in the study in order to achieve a 105-month follow-up. They underwent aortic valve repair and associated aortic root reconstruction. This prospective study is aimed at assessing the major endpoints of overall survival and freedom from reoperation. Additionally, log-rank testing for the risk factors associated with overall mortality, reoperation, and aortic valve repair failure was performed.

Results: Among 225 patients, early mortality occurred in the case of 5 patients $(2.2 \%)$, while $6(2.5 \%)$ patients experienced early valve failure. In a prospective analysis performed on the first 100 patients, long-term results achieved with KaplanMeier analysis showed a survival rate of $93 \%$ and freedom from reoperation at the level of $91.3 \%$. The risk factors for overall mortality included NYHA class, creatinine level, and perioperative root replacement as reimplantation. Redo operation was associated with bicuspid aortic valve and perioperative leaflet resection with pericardial patch repair.

Conclusions: One hundred and five month follow-up data from this prospectively analyzed cohort of patients prove that
\end{abstract}

\section{Streszczenie}

Wstęp: Zaletą operacji naprawczych jest niemal idealny efekt hemodynamiczny i uniknięcie powikłań związanych ze sztuczną protezą. Wprowadzenie funkcjonalnej klasyfikacji niedomykalności zastawki aortalnej umożliwiło systematyczne i powtarzalne podejście do plastyk kompleksu zastawki aortalnej i opuszki aorty. Brak wyników odległych uniemożliwia szerokie rekomendacje napraw aortalnych.

Cel: Prospektywna ocena plastyk zastawki aortalnej i opuszki aorty podczas 10-letniej obserwacji. Analizie poddano pierwszych 100 pacjentów operowanych w ciągu pierwszych 7 lat od wprowadzenia metody.

Materiat i metody: W latach 2003-2013 operowano 225 pacjentów z istotną niedomykalnością zastawki aortalnej, u których zaplanowano i wykonano operacje naprawcze. Analizie poddano śmiertelność wczesną i odległą, częstość reoperacji oraz czynniki wpływające na występowanie tych zdarzeń. W celu otrzymania wyników w 105-miesięcznej obserwacji, prospektywnej analizie poddano pierwszych 100 pacjentów operowanych w latach 2003-2009.

Wyniki: W całej grupie 225 chorych, w okresie okołooperacyjnym: śmiertelność - 5 chorych (2,2\%), śródoperacyjna konwersja do wymiany zastawki - 6 chorych (2,5\%). W prospektywnej odległej analizie 100 chorych przeżycie wyniosło 93\%, natomiast wolność od reoperacji -91,3. Czynnikami ryzyka dla przeżywalności były klasa NYHA i wymiana opuszki aorty, a dla reoperacji - zastawka dwupłatkowa i resekcja płatka.

Wnioski: Przedstawione pierwsze odległe wyniki kliniczne uzasadniają możliwość skutecznej operacji naprawczej kompleksu zastawki aortalnej i aorty u wybranych chorych pod warunkiem przeprowadzenia precyzyjnej oceny echokardiograficznej umożliwiającej wybór metody operacji oraz jej obiektywną kontrolę.

Słowa kluczowe: zastawka aortalna, operacja oszczędzająca zastawkę aortalną, reoperacja. 
aortic valve repair associated with aortic root reconstruction can be performed with satisfactory results.

Key words: aortic valve, aortic valve sparing surgery, reoperation.

\section{Introduction}

Interest in the use of aortic valve and aortic root repair surgery is growing as these procedures allow for sparing of the aortic valve. Valve sparing operations were first introduced by David et al. [1, 2] and Yacoub et al. [3]. Taking the aortic leaflets into consideration constituted a significant step forward, as aortic regurgitation (AR) may result from reasons other than aortic root pathology. The standardization of leaflet management was proposed by El Khoury [4]; however, the introduction of a classification of aortic regurgitation [5] and Sievers' classification of bicuspid aortic valve [6] contributed the most to the establishment of a more systematic approach.

Nevertheless, the amount of long-term data is still limited, which makes the use of aortic repair in the treatment of aortic incompetence questionable.

The aim of the study was to assess long-term results in a prospective cohort of 100 patients who underwent aortic valve repair with aortic root and ascending aorta surgery, if required. In other words, we made an attempt to determine

Tab. I. Preoperative data

\begin{tabular}{ll} 
Characteristic & $(n=100)$ \\
\hline NYH & $52.28($ SD: 17.57$)$ \\
\hline I & \\
\hline III class & $34 \%$ \\
\hline IV & $37 \%$ \\
\hline CCS class & $22 \%$ \\
\hline 0 & $7 \%$ \\
\hline I & $60 \%$ \\
\hline II & $21 \%$ \\
\hline III & $10 \%$ \\
\hline IV & $4 \%$ \\
\hline Body weight (kg) & $5 \%$ \\
\hline Height (cm) & 82.2 \\
\hline Creatinine & 175 \\
\hline CABG & 1.135 \\
\hline MV & $6 \%$ \\
\hline TV & $8 \%$ \\
\hline
\end{tabular}

NYHA - New York Heart Association, CCS - Canadian Cardiovascular Society, CABG - coronary artery bypass grafting, MV - mitral valve, TV - tricuspid valve, $\mathrm{SD}$ - standard deviation the effectiveness of different surgical techniques based on an analysis of the prognostic factors for the development of valve-related events. The list of potential risk factors encompassed both preoperative and perioperative risk factors, including different techniques of surgical management. For this purpose, a prospective observational singlecenter study was performed.

\section{Material and methods \\ Patients}

The study included 225 consecutive patients who underwent elective surgery for severe, chronic aortic regurgitation in the years 2003-2013. Preoperative transthoracic echocardiography was performed systematically; patients suitable for repair were identified and operated on according to the protocol. Early perioperative results were recorded. In order to obtain long-term follow-up data, the first 100 patients operated on between 2003 and 2009 were identified and included in the prospective follow-up study. These data were verified with the National Death Registry in 2012, it allowed us to achieve $100 \%$ accuracy with regard to primary endpoint data. Patient characteristics are presented in Table 1.

\section{Study design and data collection}

The study was conducted as a prospective single-centre observational study.

The data were collected by reviewing the patients' records, most importantly the data from the Polish National CTS Registry. As part of the prospective study, the patients were routinely scheduled for echocardiographic assessment - immediately after surgery, after one year, and yearly thereafter, if deemed necessary.

For the purpose of the statistical analysis of long-term results, including risk factors, Kaplan-Meier survival analysis and Kaplan-Meier survival analysis with log-rank test were used to compare the groups; $p$ values $<0.05$ were considered as statistically significant. All analyses were performed using SigmaPlot 10.0 (Systat Software Inc, San Jose, USA).

\section{Echocardiography}

Perioperative transesophageal echocardiography (TEE) was performed in a standardized manner, according to the current guidelines published by the American Society of Echocardiography, the Society of Cardiovascular Anesthesiologists, and the European Society of Echocardiography. It was performed for the first time after the induction of general anesthesia, before cardiopulmonary bypass (CPB), and then repeated at the end of the procedure. Additionally, to assess the changes in left ventricular dimensions 
and ejection fraction, transthoracic echocardiography (TTE) was carried out 1 month after the surgery.

The required echocardiographic views (parasternal long axis, apical four- and five-chamber) with pre-specified $2 \mathrm{D}$ cineloops, M-mode, and Doppler were recorded in digital format. Based on the M-mode recordings of the left ventricle (LV), end-systolic and end-diastolic dimensions were measured using leading edge methodology [7]. Measurements were taken for a mean of three consecutive beats when the patient was in sinus rhythm or five consecutive beats if the patient was in atrial fibrillation. All measurements were carried out in accordance with the recommendations of the American Society of Echocardiography [7]. Valve effective orifice area, fractional shortening, and ejection fraction were calculated. Left ventricle mass was calculated using the Penn Convention formula. Aortic flow velocities were assessed using continuous wave Doppler, while LV outflow velocities and LV filling were assessed with pulse-wave Doppler.

\section{Clinical management}

The patients were selected for aortic repair on the basis of TTE, but in some cases preoperative TEE was also performed. Precise echocardiographic analysis included: anatomical features (tricuspid vs bicuspid, type of bicuspid anatomy), the character of AR, the presence of prolapse, the direction of the resulting aortic regurgitant jet, leaflet pliability, the sizes of the annulus, aortic root, sino-tubular junction (STJ), and aorta. The aortic root was considered as large when its size was at least $4.5 \mathrm{~cm}$ in bicuspid and $5 \mathrm{~cm}$ in tricuspid anatomy, in accordance with the current recommendations. The criteria for severe AR were compliant with the current recommendations.

For the purpose of treatment standardization, the key component of preoperative assesment throughout the entire study was to define the type of AR, taking into account the anatomy of the aortic root and the importance of the functional aortic annulus (FAA). According to the functional classification introduced by El Khoury [5], there are 3 classes of AR related to aortic valve or root structural abnormality, which directly influence the type of repair suitable for each structurally abnormal element responsible for valve incompetence (see the methods section).

\section{Operation}

The operation begun with the use of TEE and a thorough examination of the valve according to the protocol. All operations were performed via median sternotomy. Standard cardiopulmonary bypass was performed in normothermia with cannulation of the ascending aorta and the right atrium. During the bypass, packed cell volume was maintained within $20-25 \%$ (mean $24 \%$ ), while pump flow was maintained within $2.0-2.5 \mathrm{l} / \mathrm{min} / \mathrm{m}^{2}$. The initial dose of cold blood cardioplegia of $15 \mathrm{cc} / \mathrm{kg}$ (usually $900 \mathrm{ml}$ ) with a $1: 4$ ratio of cold St. Thomas cardioplegia to blood was administered into the aortic root or coronary ostia at the rate of $300 \mathrm{ml} / \mathrm{min}$. During the cross-clamp period, 400 $\mathrm{ml}$ of cardioplegia was administered antegradely every 20 minutes.

The aorta was opened transversely, $1.5 \mathrm{~cm}$ above the STJ. For the purpose of valve assesment, two to three retraction stay sutures (4-0 prolene) were applied at the highest point of each commissure and put under vertical tension. Appropriate height of the free edge and level of coaptation were determined. Next, leaflet prolapse was identified based on the different levels and relative height of leaflets protruding into the LV outflow tract. The length of the free margin was assessed in relation to the opposite leaflet. Perioperative analysis of the aortic valve was preceded by meticulous TEE assessment.

The selected repair procedure depended on the type of $A R$, in accordance with the following functional classification:

- Type I: Functional annulus dilatation (FAA) with central aortic regurgitation (AR).

In Type la (enlargement of the aorta and the STJ), STJ remodeling was performed with the size of the aortic Dacron prosthesis equal to the size of the ventriculo-aortic junction. The anastomosis between the root and the Dacron graft had to have equal spacing between each commissural part of the STJ.

In Type Ib (enlargement of the aorta and the aortic root), root remodeling was performed when the diameter of the aortic annulus was below $28 \mathrm{~mm}$. The size of the Dacron prosthesis was based on the diameter of the ventriculo-aortic junction. Aneurysmal sinuses were replaced with separate patches made from the same Dacron prosthesis.

In Type Ic (enlargement of the aortic annulus), subcommissural annuloplasty was performed with 2-0 braided sutures with pledgets, which were applied in the middle of the height of the subcommissural triangles.

When all components of the root were enlarged, aortic valve reimplantation was performed. Initially, a straight Dacron graft was used. The size of the Dacron graft was based on the diameter of the STJ, providing satisfactory leaflet coaptation. In 2009, a modification of the reimplantation procedure was introduced, which consists in the use of a Valsalva Dacron graft reflecting the unique anatomy of the aortic root. In such cases, the size of the Dacron prosthesis was based on the height of the non-left commissure. During reimplantation, the proximal line consisted of ten interrupted, 2-0 pledgeted sutures at the ventriculoaortic junction, then implanted horizontally to the Dacron prosthesis. The trimmed aortic valve was implanted to the prosthesis with 4-0 monofilament sutures in a continuous fashion, starting from the nadir of each leaflet.

- Type II: Aortic leaflet prolapse with eccentric AR.

Aortic leaflet prolapse was managed with either leaflet free edge remodeling or leaflet plication. The leaflet free edge remodeling consisted of continuous Gore-Tex 7-0 suture, running along the free edge, effectively shortening its length. The leaflet plication of the prolapsing leaflet was performed in the middle of the leaflet edge with 6-0 prolene sutures [8]. 
- Type III: Leaflet restriction causing eccentric AR of the opposite direction usually was considered as a contraindication for valve repair.

Bicuspid aortic valve (BAV). The BAV combines several mechanisms, including types Ia, Ic, II, III of aortic valve regurgitation.

The repair technique applied in this case includes subcommissural annuloplasty combined with raphe excision and plication of the prolapsing segment. Alternatively, Gore-Tex free edge remodeling was applied. Stabilization of repair usually requires aortic root and STJ remodeling with aorta replacement [9].

\section{Results}

\section{Early outcomes}

Baseline characteristics for all 225 patients undergoing aortic valve repair between 2003 and 2013 included: mean age -52.1 years ( \pm 17.5 years SD); male gender $-75 \%$; NYHA class III/IV - 32\%; mean creatinine - $1.22 \mathrm{mg} / \mathrm{dl}( \pm 1.5 \mathrm{mg} / \mathrm{dl}$ $\mathrm{SD})$; mean body weight $-83.2 \mathrm{~kg}( \pm 9.9 \mathrm{~kg} \mathrm{SD})$; and mean height $-176.1 \mathrm{~cm}( \pm 9.9 \mathrm{~cm} \mathrm{SD})$. Comorbidities included: smoking $-46 \%$, hypertension $-63 \%$, hyperlipidemia $-36 \%$,

Tab. II. Perioperative outcome

\begin{tabular}{|c|c|}
\hline Variable & $(n=100)$ \\
\hline TAV & $73 \%$ \\
\hline BAV & $27 \%$ \\
\hline \multicolumn{2}{|l|}{ Leaflet repair } \\
\hline Plication & $13 \%$ \\
\hline Gore-Tex & $13 \%$ \\
\hline Resection/patch & $14 \%$ \\
\hline Shaving & $14 \%$ \\
\hline \multicolumn{2}{|l|}{ Functional annulus stabilization } \\
\hline Subcommissural annuloplasty & $62 \%$ \\
\hline STJ remodelling & $6 \%$ \\
\hline Remodeling - STJ + asc. aorta & $19 \%$ \\
\hline Remodeling - root & $13 \%$ \\
\hline \multicolumn{2}{|l|}{ Root stabilization } \\
\hline Remodeling - overall & $32 \%$ \\
\hline Reimplantation & $30 \%$ \\
\hline $\mathrm{EF}(\%)$ & 53.2 \\
\hline Graft size $(\mathrm{mm})$ & 25.8 \\
\hline Cross-clamp (min) & 88.1 \\
\hline Cardiopulmonary bypass & 126.8 \\
\hline Temp. on CPB & 34.2 \\
\hline Ventilation time & 22.9 \\
\hline
\end{tabular}

TAV - transcatheter aortic valve, BAV - bicuspid aortic valve, STJ - sino-tubular junction, $\mathrm{EF}$ - ejection fraction, $\mathrm{CPB}$ - cardiopulmonary bypass and diabetes - 43\%. Classification categories included: type $\mathrm{la} / \mathrm{lb}-60$; type $\mathrm{lb}+\mathrm{lc}-61$; type $\mathrm{la}+\mathrm{lb}+\mathrm{lc}-99$, and type II - 111. Tricuspid valves were present in 150 patients and bicuspid in 75. Leaflet repair consisted in free edge remodeling with 7-0 Gore-Tex sutures in 27, leaflet plication in 63, and triangular resection with or without a patch in 24 cases. The techniques applied for functional annulus stabilization (FAA) included subcommissural annuloplasty (99 patients), external annuloplasty with a Dacron graft (main author's technique - 19 patients), reimplantation (61 patients), and STJ stabilization alone (15 patients). Aortic root replacement was performed either as a reimplantation - David I operation (in 61, including Valsalva modification in 39 patients) - or as remodeling - David II or Yacoub operation (in 60 cases including 18 cases with all sinuses replaced). The aorta was replaced in 121 patients. Twentyone patients had concomitant CABG, 17 underwent mitral procedures, and 6 had tricuspid valve surgery. In-hospital mortality was $2.2 \%(n=5)$. The causes included multiorgan failure $(n=3)$ and congestive heart failure $(n=2)$.

Mean cardiac ischemic time was 85.9 min, while average cardiopulmonary bypass time was $123.6 \mathrm{~min}$. There were 6 procedural conversions or reoperations on a single admission (2.5\%), which included: root remodeling failure in 1, BAV repair failure in 2, and tricuspid prolapse treated with Gore-Tex remodeling in 3 patients. Prosthetic valve replacements were performed in all cases, including Bentall operations in 2 patients. No deaths or procedural complications occurred in the patients undergoing the conversion.

The preoperative data and intraoperative outcomes of the prospectively analyzed cohort of 100 patients are presented in Table I and Table II, respectively.

\section{Late outcomes}

Five patients died during follow-up. Overall survival at 105 months of 100 patients cohort was $93 \pm 1.9 \%$. There were 6 late reoperations. Two of them were not valve-related and resulted from acute dissection of the aortic arch and descending aorta $(n=1)$ and chronic dissection of the descending aorta in a Marfan syndrome patient. Other reoperations were caused by the following: VSD at the level of the perimembranous septum $(n=1)$ and BAV complex repair failure after raphe excision with pericardial patch implantation and additional Gore-Tex stabilization. The overall freedom from reoperation was $91.3 \%$.

There were five patients who developed moderate-tosevere $A R$ and overall freedom from repair failure - SVD (structural valve deterioration) at 5 years was $93 \pm 3.2 \%$.

There was one death - late after emergency reoperation for type $\mathrm{B}$ dissection. The overall results are presented in Figure 1.

\section{Risk factors analysis}

The prognostic factors for valve related-events, such as survival, reoperation, and repair failure, are presented in Figures 2, 3, and 4, respectively. 
A

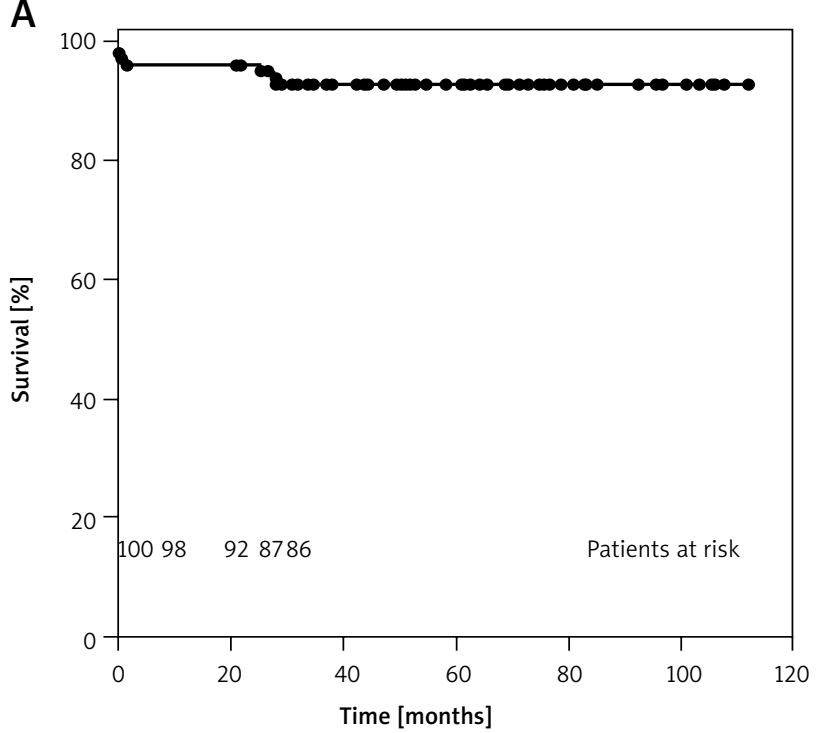

B

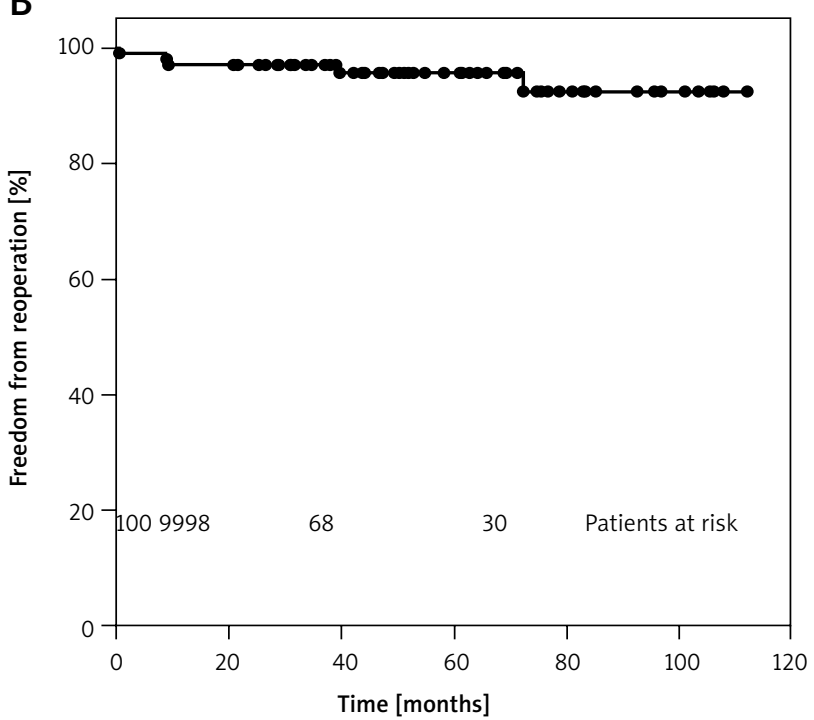

C

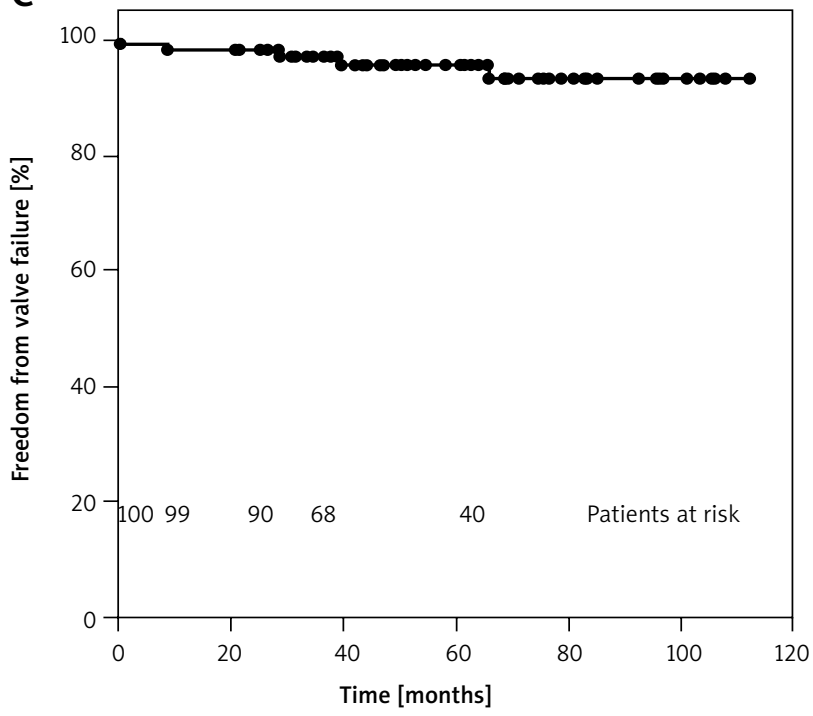

Fig. 1. Overall survival, freedom from reoperation and repair failure
A

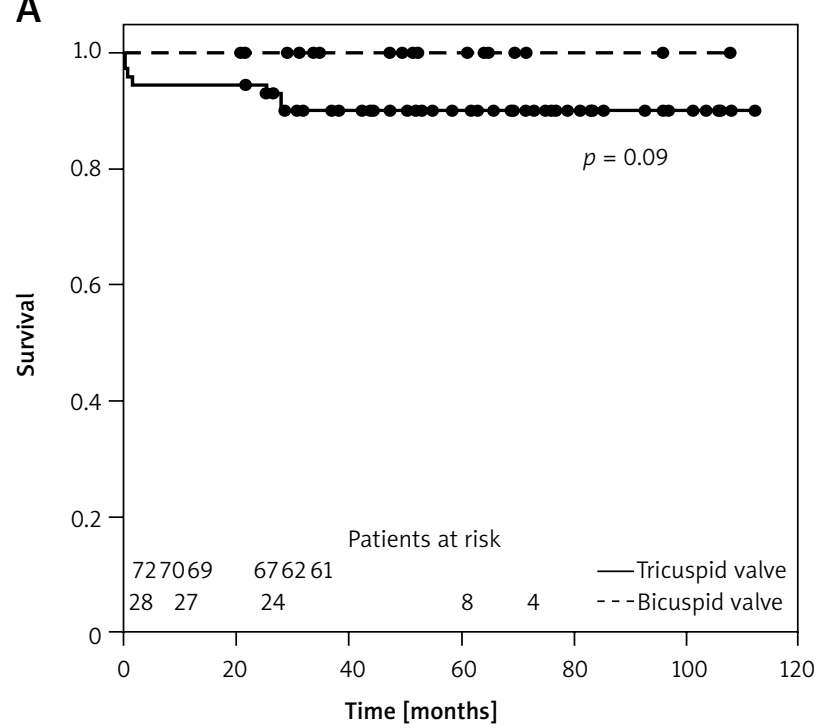

B

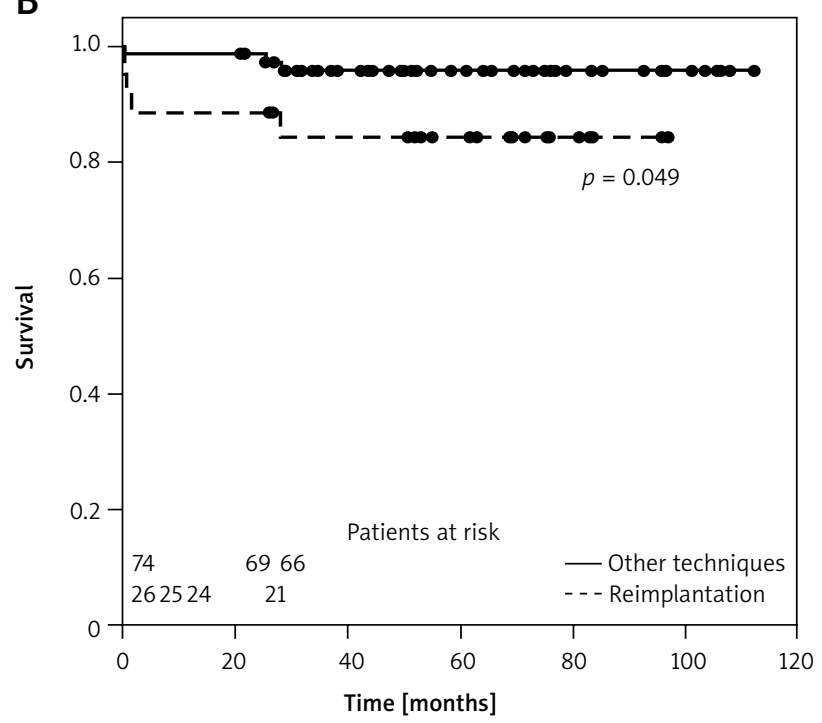

C

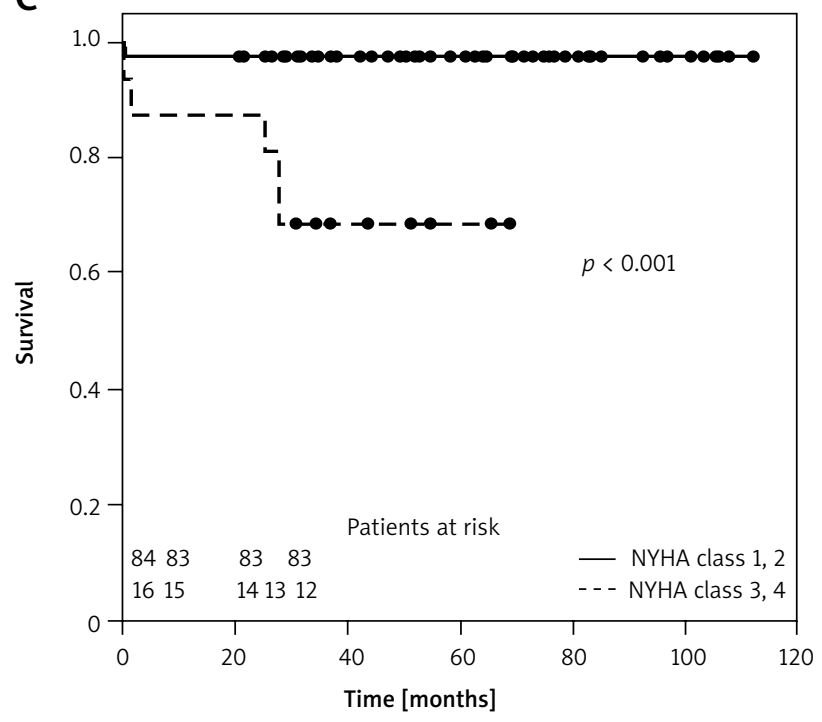

Fig. 2. Predictors of survival 
A

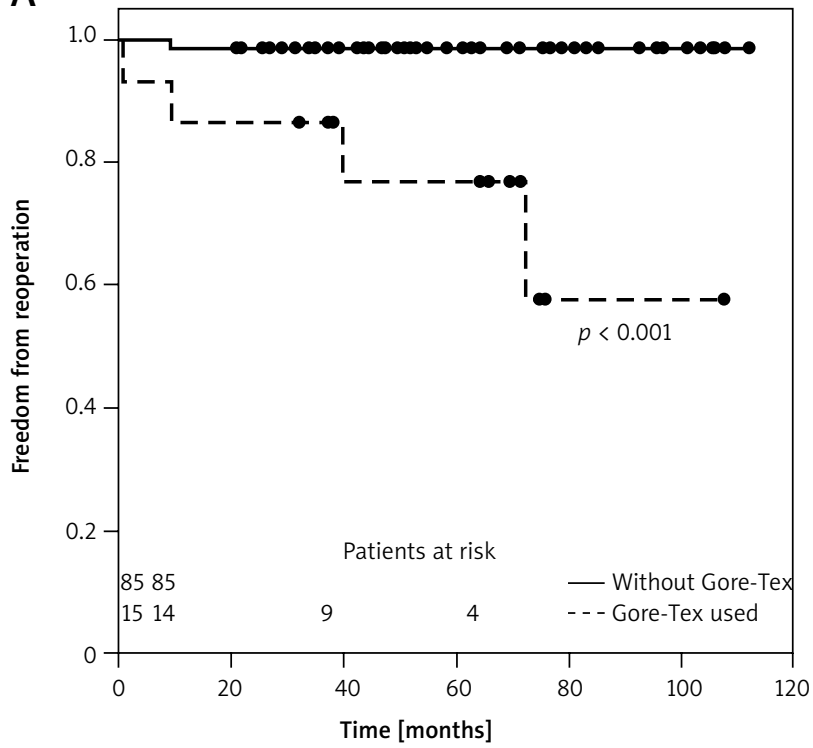

B

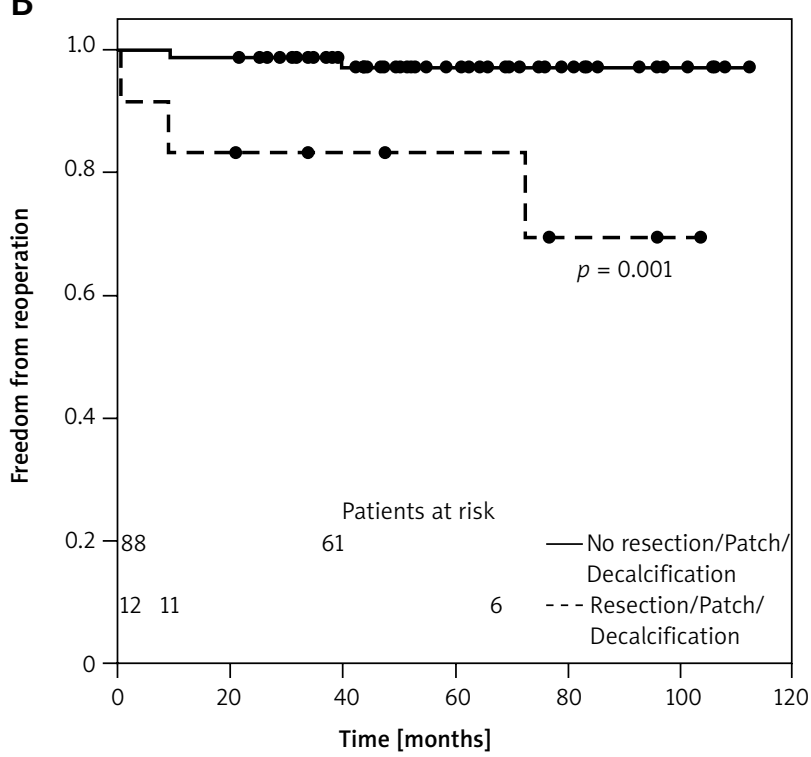

Fig. 3. Predictors of reoperation

Risk factors for long-term survival included NYHA class, creatinine level, and aortic replacement with valve reimplantation.

Risk factors for reoperation included leaflet resection with and without patch and Gore-Tex for free edge remodeling.

Risk factors for aortic repair failure and aortic valverelated reoperation included bicuspid aortic valve, GoreTex leaflet edge remodeling, and leaflet resection with and without patch.

\section{Discussion}

Aortic valve repair or aortic valve-sparing surgery is a treatment of valve incompetence, which is utilized less frequently than valve replacement. The reason behind this state of affairs is most likely the lack of a widely accepted systemic approach allowing for reproducible results.

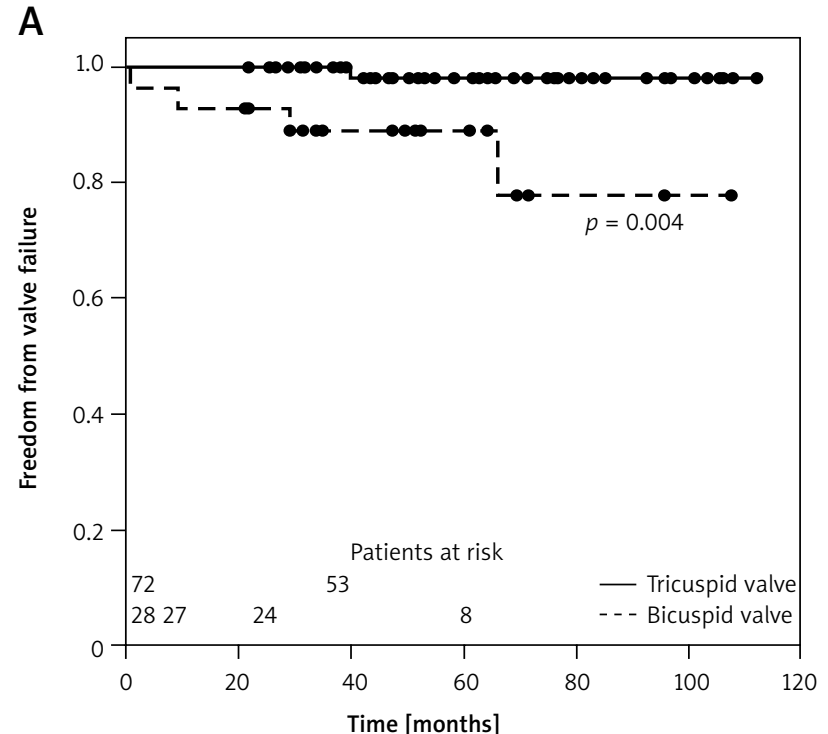

B

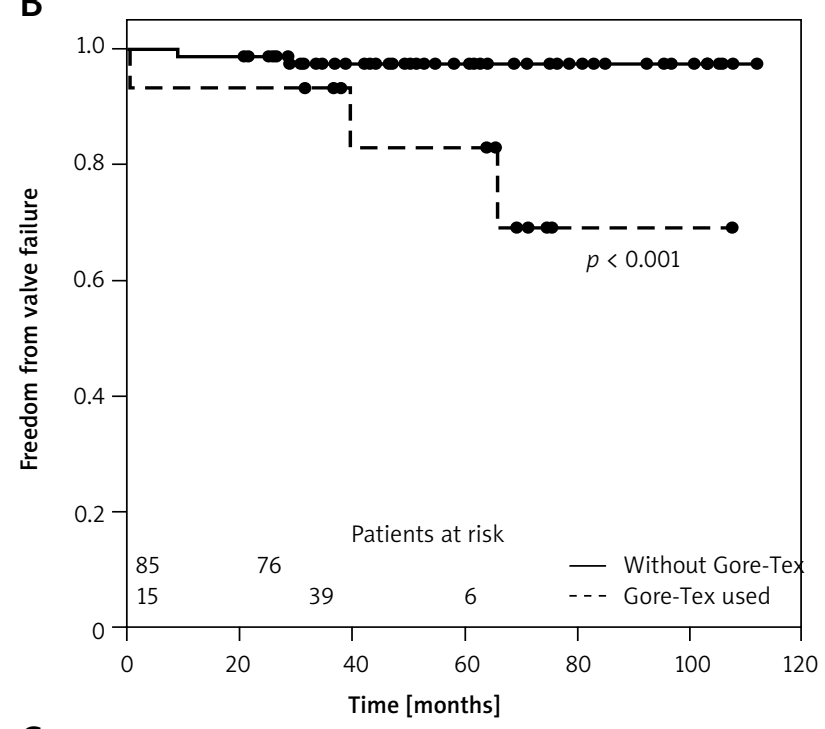

C

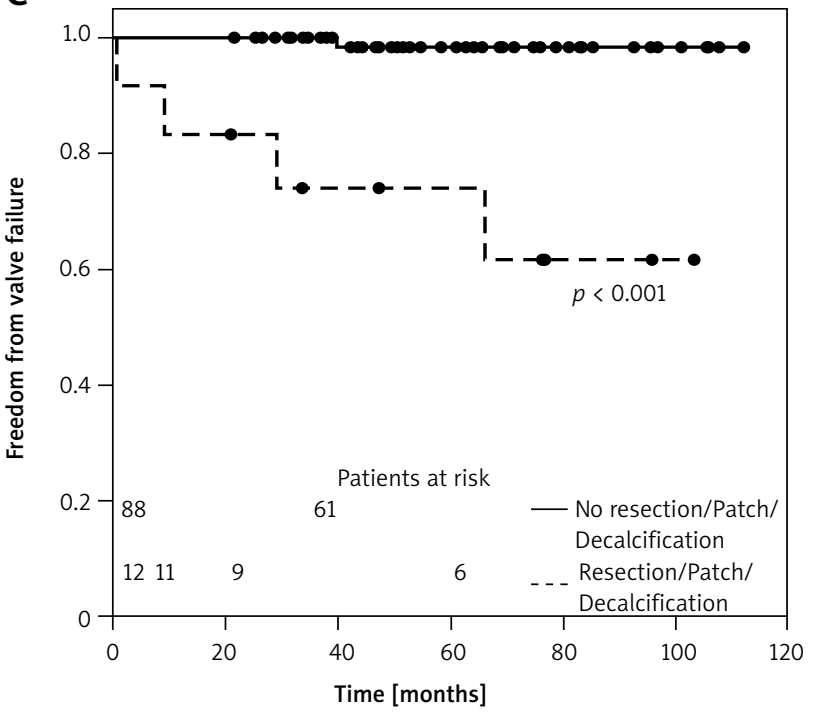

Fig. 4. Predictors of late postoperative structural valve deterioration (SVD) - repair failure (severe AR) 
The patients were analyzed in accordance with a strict, prospective protocol, which included precise identification of the mechanisms of aortic valve regurgitation and selection of an appropriate surgical technique [10].

In this single-center prospective study, we showed that $A R$ repair with and without aortic treatment in a group of selected patients is a feasible technique providing satisfactory long-term results with regard to survival, freedom from reoperations, and aortic valve failure. Complete echocardiographic follow-up proves a significant improvement of left ventricular parameters. There are very few studies looking at the overall population undergoing aortic repair surgery regardless of the type of pathology and surgical technique used. The largest available long-term study, presented by Boodhwani et al., during an 8-year-long follow-up of 264 patients, found an overall survival of $87 \%$, freedom from reoperations of $91 \%$, and freedom from repair failure and severe aortic valve regurgitation of $79 \%$ [10]; our results were comparable.

The strongest predictors of mortality were creatinine level and NYHA class higher than grade III. Congestive heart failure is a widely recognized risk factor for mortality in AR patients [11, 12]. Interestingly, creatinine level was found to be a very potent predictor of unfavorable outcome.

Reimplantation of the aortic valve and David I procedure were also found to be related to survival, although this was strictly limited to the early postoperative period, which might be related to the high complexity of this procedure reflected by its long ischemic times. Interestingly, there were no late events in this subgroup of patients, which confirmed the durability of this method. David et al. found $95 \%$ freedom from severe valve failure at 10 years [2], while Shrestha et al. established the level of freedom from reoperation after 10 years at $85 \%$ [13]. These results are confirmed by the very few late cardiac-related events observed after the reimplantation type of aortic valve sparing procedures $[1,2,13]$.

The strongest predictor for the recurrence of aortic regurgitation was bicuspid aortic valve. Bicuspidity probably still remains the most controversial topic in aortic valve repair. Boodhwani et al. found similar long-term results for bicuspid and tricuspid aortic valve repair procedures [10], which were confirmed by Aicher et al. in their study [14]. In separate analyses of patients with bicuspid valves, Boodhwani et al. described perioperative factors which negatively influence the durability of the repair [15]: raphe resection and the use of a patch during leaflet repair. Besides, stabilization of repair with reimplantation into the prosthesis provides better results than subcommissural annuloplasty with aortic replacement and STJ remodeling. Aicher et al. found that patch implantation after conjoined raphe resection constitutes a negative prognostic factor. Root remodeling, in contrast to subcommissural annuloplasty, provided better outcomes [9]. Those findings corroborate ours. Interestingly, patients with bicuspid valves showed better long-term survival then those with tricuspid valves. The research conducted by Ali et al., comparing similar groups, confirmed better outcomes of patients with bicuspid valves [7].

We found that Gore-Tex-free edge remodeling is a predictor for the recurrence of valve incompetence and reoperation. Gore-Tex stabilization of the free margin is indicated in complex repairs, such as in the case of a bicuspid valve, prolapse of more than one leaflet, or fenestrations. On the other hand, de Kerchove et al. reported worse results of Gore-Tex stabilization. One of the possible mechanisms responsible for this outcome may be overcorrection [16, 17].

Subcommissural annuloplasty was successfully used in the majority of patients as a method of annular stabilization. The durability of this method was proven for patients with tricuspid aortic valve [8].

\section{Conclusions}

The gathered 105-month follow-up data from a prospectively analyzed cohort of patients proves that aortic valve repair associated with aortic root reconstruction can be performed with satisfactory results. The long-term results that we achieved prove its durability.

However, the results can be improved with more aggressive root stabilization in bicuspid aortic valve repair. Similarly, more liberal use of plication as a technique of choice during leaflet repair may help achieve a lower level of aortic regurgitation recurrence.

\section{Disclosure}

Authors report report no conflict of interest.

\section{References}

1. David TE, Feindel CM. An aortic valve-sparing operation for patients with aortic incompetence and aneurysm of the ascending aorta. J Thorac Cardiovasc Surg 1992; 103: 617-622.

2. David TE, Feindel CM, Webb GD, Colman JM, Armstrong S, Maganti M. Aortic valve preservation in patients with aortic root aneurysm; results of the reimplantation technique. Ann Trhorac Surg 2007; 83: S732-S735.

3. Yacoub MH, Gehle P, Chandrasekaran V, Birks EJ, Child A, Radley-Smith R. Late results of a valve sparing operation in patients with aneurysm of aorta and root. J Thorac Cardiovasc Surg 1998; 115: 1080-1090.

4. Price J, De Kerchove L, El Khoury G. Aortic valve repair for leaflet prolapse. Semin Thorac Cardiovasc Surg 2011; 23: 149-151.

5. El Khoury G, Glineur D, Rubay J, Verhelst R, d'Acoz Y, Poncelat A, Astarci P, Noirhomme $P$, van Dyck M. Functional classification of aortic root/valve abnormalities and their correlation with etiologies and surgical procedures. Curr Opin Cardiol 2005; 20: 115-121.

6. Sievers $\mathrm{HH}$, Schmidtke C. A classification system for the bicuspid aortic valve from 304 surgical specimens. J Thorac Cardiovasc Surg 2007; 133: 1226-1233.

7. Ali A, Patel A, Ali ZA, Abu-Omar Y, Freed D, Sheikh AY, Athanasiou T, Pepper J. Stentless aortic valve replacement in patients with bicuspid aortic valve. Eur J Cardiothorac Surg 2010; 38: 134-140.

8. Boodhwani M, de Kerchove L, Glineur D, Vanoverschelde JL, Noirhomme P, El Khoury G. Assesment and repair of aortic valve cusp prolapse: implications for valve-sparing procedures. J Thorac Cardiovasc Surg 2011; 141: 917-925.

9. Aicher D, Langer F, Adam O, Tscholl D, Lausberg H, Schafers H. Cusp repair in aortic valve reconstruction. J Thorac Cardiovasc Surg 2007; 134: 1533.

10. Boodhwani M, De Kerchove L, Glineur D, Poncelet A, Rubay J, Astarci P, Verhelst R, Noirhomme P, El Khoury G. Repair-orientated classification of aortic insufficiency: impact on surgical techniques and clinical outcomes. J Thorac Cardiovasc Surg 2009; 137: 286-294. 
11. Badiu C, Bleiziffer S, Eichinger W, Zaimova I, Hutter A, Mazitelli D, Voss B, Lange R. Are bicuspid aortic valves a limitation for aortic valve repair? Eur J Cardiothorac Surg 2011; 40: 1097-1104.

12. Boodhwani M, De Kerchove L, Glineur D, Poncelet A, Rubay J, Vanovarschelde JL, Van Dyck M, Noirhomme P, El Khoury G. Aortic valve repair with ascending aortic aneurysm: associated lesions and adjunctive techniques. Eur J Cardiothorac Surg 2011; 40: 424-428.

13. Shrestha M, Pichlmaier M, Baraki H, Meading I, Fitzner S, Sarikouch S, Khaladj N, Hagl C, Haverich A. Long term results after aortic valve-sparing operation. Eur J Cardiothorac Surg 2012; 41: 56-62.

14. Aicher D, Langer F, Adam O, Tscholl D, Lausberg H, Schäfers H. Bicuspid valve repair. Circulation 2011; 123: 178-185.
15. Boodhwani M, de Kerchove L, Glineaur D, Rubay J, Vanoverschelde JL, Noirhomme P, El Khoury G. Repair of regurgitant bicuspid aortic valves: a systemic approach. J Thorac Cadiovasc Surg 2010; 140: 276-284.

16. de Kerchove L, Boodhwani M, Glineur D, Poncelet A, Rubay J, Vanovarschelde JL, Noirhomme P, El Khoury G. Cusp prolapse repair in trileaflet aortic valves: free margin plication and free margin resuspension techniques. Ann Thorac Surg 2009; 88: 455-461.

17. de Kerchove L, Glineur D, Poncelet A, Boodhwani M, Rubay J, Dhoore W, Noirhomme P, El Khoury G. Repair of aortic leaflet prolapse, a ten year experience. Eur J Cardiothorac Surg 2008; 34: 780-784. 